\title{
An unusual pleomorphic adenoma
}

\author{
Adenoma pleomórfico não usual
}

Christiano Sampaio QUEIROZ

Roberto Almeida de AZEVEDO'

Antonio Irineu TRINDADE NETO'

Caetano Guilherme Carvalho PONTES'

Rafael de Queiroz MOURA²

\begin{abstract}
Pleomorphic adenoma is the most common neoplasm in major and minor salivary glands. It constitutes approximately $90 \%$ of all benign salivary gland lesions and the parotid is the most affected location. When the minor salivary glands are affected, it mostly occurs at the junction of the hard and soft palates. The diagnosis is complex because of the great histological variety and biological behavior of this tumor, a histopathological examination being essential. The recommended treatment is surgical excision. For lesions located superficially in the parotid gland, superficial parotidectomy - identifying and preserving the facial nerve - is necessary. Lesions in the palate or gums sometimes demand a margin of safety, being excised below the periosteum, including the overlying mucosa. With correct surgical removal, the prognosis is excellent. The aim of this study is to report a case of an unusual minor salivary gland pleomorphic adenoma in the hard palate, describing the most important aspects of this pathology.
\end{abstract}

Indexing terms: Neoplasms. Pleomorphic adenoma. Salivary glands.

\section{RESUMO}

O adenoma pleomórfico é a neoplasia mais comum entre os tumores das glândulas salivares maiores e menores. Constitui aproximadamente $90 \%$ de todas as lesões benignas das glândulas salivares e a parótida é a mais acometida. A junção dos palatos duro e mole é o sítio de predileção mais comum, quando as glândulas salivares menores são atingidas. O diagnóstico é complexo devido a grande variedade histológica e comportamento biológico deste tumor, sendo imprescindível a realização do estudo histopatológico. O tratamento de escolha é a excisão cirúrgica. Para as lesões localizadas no lobo superficial da parótida é recomendada a parotidectomia superficial com a identificação e preservação do nervo facial. As lesões do palato ou gengiva por vezes podem exigir margem de segurança, sendo geralmente excisadas abaixo do periósteo, incluindo a mucosa sobrejacente. Com a remoção cirúrgica adequada, o prognóstico é excelente. O presente trabalho tem como objetivo relatar um caso de adenoma pleomórfico não usual de glândula salivar menor no palato duro, em região posterior direita, além de descrever os aspectos mais importantes dessa patologia.

Termos de indexação: Neoplasias. Adenoma pleomorfo. Glândulas salivares.

\section{INTRODUCTION}

Tumors of the salivary glands, though uncommon, are not that rare and constitute an important field in oralmaxillofacial pathology. The diversity of histological aspects displayed by neoplasms of the salivary glands causes great difficulty in terms of universal classification ${ }^{1-2}$.

Pleomorphic adenoma (PA) is the most commonly found neoplasm amongst tumors of the major and minor salivary glands, originally called a mixed benign tumor in $1866^{3-5}$. The change of name to "pleomorphic" adenoma was first suggested as recently as 1948, as this term describes the embryological basis for these tumors, which originate in the epithelial and connective tissue ${ }^{3}$.
The classical microscopic description was applied in 1874, observing a variety of cell types as the main characteristic of pleomorphic adenoma, not just between the different samples examined but also in different parts of the same sample ${ }^{6}$. Even though it has an origin which is exclusive to epithelial tissue, the variety of components accords it a mesenchymal appearance as a result of the production of secretions from the tumor cells themselves, which may be ductal or myoepithelial ${ }^{7}$.

PA makes up approximately $90 \%$ of all benign lesions of the salivary glands ${ }^{5,8-11}$. It represents between $53 \%$ and $77 \%$ of parotid tumors, $44 \%$ to $68 \%$ of tumors of the submandibular gland and $33 \%$ to $43 \%$ of tumors of the minor salivary glands². It almost never manifests

\footnotetext{
${ }^{1}$ Universidade Federal da Bahia, Hospital Santo Antônio - Obras Sociais Irmã Dulce, Programa de Residência e Especialização em Cirurgia e Traumatologia Bucomaxilofacial. Av. Bonfim, 161, Largo de Roma, 40420-000, Salvador, BA, Brasil. Correspondência para / Correspondence to: AI TRINDADE NETO. E-mail: <antonioneto.bucomaxilo@gmail.com>.

${ }^{2}$ Universidade Estadual do Sudoeste da Bahia, Faculdade de Odontologia. Jequié, BA, Brasil.
} 
itself in other areas of the head and neck. It occurs most frequently in the parotid gland and is more prevalent in women (1.5:1) and in black people ${ }^{6}$. The lesions may appear at any age, though rarely in children, being most common between the fourth and sixth decades of life $5^{5,8,12}$.

Clinically, they are described as nodular lesions with a smooth surface that generally present without pain, having a firm consistency, slow growth and which do not attach themselves to the adjacent tissue (mobile lesion except when occurring in the hard palate). In the majority of cases it does not cause ulceration of the overlying mucosa ${ }^{3}$. The minor salivary glands, when affected, are normally located, in order of prevalence, at the junction of the hard and soft palates, lips, tongue, cheeks and floor of the mouth; the histological description in these cases is similar to that of adenomas of the major salivary glands $13,10,12$.

The diagnosis of pleomorphic adenoma is performed based on a detailed clinical history and physical examination. Imaging exams, though not essential, have demonstrated a prominent role in establishing the origin, location and limits of the lesion, particularly tomographic techniques. Conventional radiography is limited, only being useful for the screening of lesions adjacent to mineralized tissue. Ultrasound (US), in spite of it not being invasive, is useful for differentiating between intraglandular and extraglandular lesions, but is also limited to the evaluation of the deep spaces in the region of the head and neck, particularly via interposition of the bone. Computer tomography $(\mathrm{CT})$ is particularly recommended for identifying lesions with bone involvement, however it does not provide good definition of soft tissue detail, hindering the differential diagnosis of those lesions located deep in the region of the head or neck. Magnetic resonance imaging (MRI) is a tomographic technique that offers high definition of the soft tissue, permitting differentiation between lesions and better distinction between the salivary gland, lesion and adjacent tissue ${ }^{6,10}$. Fine-needle aspiration puncture (FNAP) is another mode of diagnosis that could be used in terms of determining if the tumor is benign or not; however, it does not serve to define treatment ${ }^{5}$. The definitive diagnosis of pleomorphic adenoma, therefore, is carried out by means of a histopathological examination ${ }^{6,10}$.

A pleomorphic adenoma is a tumor with great histopathological variety, its characteristics including the occurrence of various architectural and structural arrangements and variations in cellularity, sometimes in just one sample. The lesion consists of epithelial, myoepithelial and mesenchymal elements, enclosed in a stroma that is myxoid, chondroid or even osteoid in nature ${ }^{6,10}$. As far as Lima et al. ${ }^{1}$ are concerned, the diversity of histological aspects exhibited by neoplasms of the salivary gland has been attributed to the presence of the myoepithelial cell in these glands.

Lesions located in the minor salivary glands are histologically similar to those occurring in the major salivary glands, despite there being a tendency for many of the lesions in those glands to be predominantly cellular, with a minimum of stroma and cartilage component. Either they have no fibrotic capsule formation or just a very thin capsule, giving them the false impression of infiltration into the adjacent tissue. Another important characteristic is that they can present with incomplete encapsulation, particularly along the surface portion of those located in the palate, below the epithelial surface. Occasionally they may present neighboring, extracapsular lesions which, in cross-sectional images, show up as pedunculated areas of growth external to the principal neoplasm ${ }^{6,10}$.

With the larger lesions, necrosis, hemorrhage and calcification or ossification may be present. The presence of areas of necrosis, atypical mitoses, invasiveness and extensive hyalinization suggests the possibility of malignancy. On the other hand, calcifications inside the mass suggest a benign neoplasm or, less commonly, schwannoma or mucoepidermoid carcinoma 1,5,10,13-14. Even though it has well-known clinical and morphological characteristics, the malignancy of the pleomorphic adenoma is the holder of a pathogenesis which is still uncertain, as is the expression of oncogenes and the factors that influence its transformation ${ }^{11}$.

In the long run, malignant degeneration may occur, which is most likely in adenomas that have been evolving for over ten years. Therefore, early diagnosis is necessary and should be followed up by a suitable approach to treatment. Malignant neoplasms in the minor salivary glands represent less than $2 \%$ of all cases of tumors ${ }^{4}$. However, neoplasms in these glands that go untreated may undergo a malignant transformation in between $5 \%$ and $25 \%$ of cases, resulting in carcinoma ex-pleomorphic adenoma (Ca-ex-PA) ${ }^{10}$.

The treatment of choice is surgical removal. For lesions located in the superficial lobe of the parotid, a superficial parotidectomy is recommended with the identification and preservation of the facial nerve. Lesions of the palate or gums may sometimes demand a margin of safety, normally being surgically removed below the periosteum, including the overlying mucosa. The removal of bone is not generally required as the pleomorphic adenoma does not invade the bone tissue, although it may cause resorption from pressure. Given correct surgical removal, the prognosis is excellent ${ }^{1-3,6,10,15}$. 
The aim of the present study is to report an unusual case of a malodorous, pleomorphic adenoma of the minor salivary gland in the hard palate, with an extensive area of surface necrosis, resembling a malign tumor.

\section{CLINICAL CASE}

Female patient aged 21, pheoderma, appeared at the clinic of the Santo Antônio Hospital for Oral Maxillofacial Surgery and Traumatology - Sister Dulce Charitable Works Foundation, complaining of "something odd in the roof of her mouth" and reporting an evolution of a little over a year. Upon clinical examination, a volumetric increase was observed to the rear and right hand side of the hard palate, unique, fixed, circumscribed, hardened on palpation, with a large area of necrosis, without pain and malodorous, measuring $30 \mathrm{~mm}$ at its largest diameter, presenting with

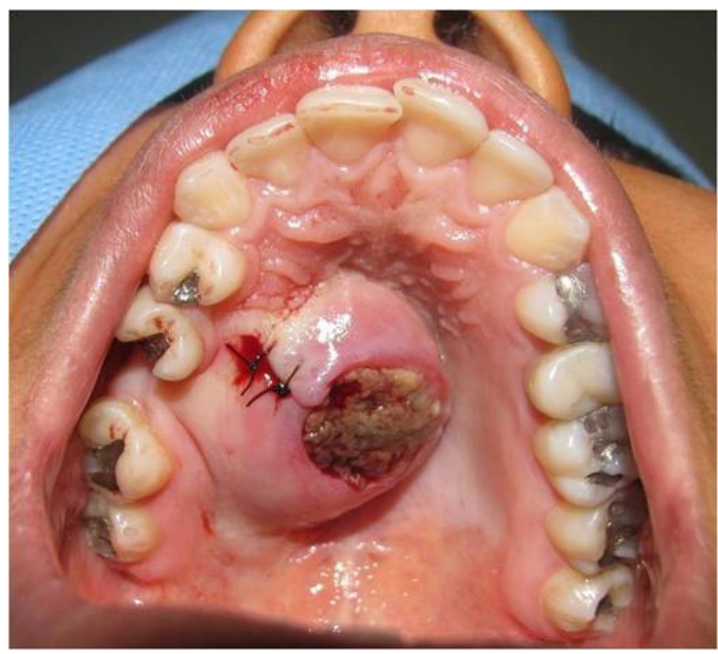

Figure 1. Immediate post-operative (incisional biopsy). Observe the large area of necrosis. characteristics of nodular lesion and with a sessile base (Figure 1). On tomographic examination, a well-defined lesion was found, circumscribed in the right maxilla, with an area of superficial osteolysis in the hard palate, and no invasion of adjacent structures (Figure 2).

An incisional biopsy was performed, the histopathological examination of which diagnosed an ulcerated pleomorphic adenoma. Subsequently, the patient was subjected to a surgical procedure under general anesthetic for the complete surgical removal of the lesion, in which an intrasulcular incision of the palate was performed extending from the right molars to the left pre-molars, with the subsequent dissection of the mucoperiosteum. In the trans-operative period, an encapsulated lesion was observed, well circumscribed and with signs of superficial osteolysis on the palate (Figure 3).

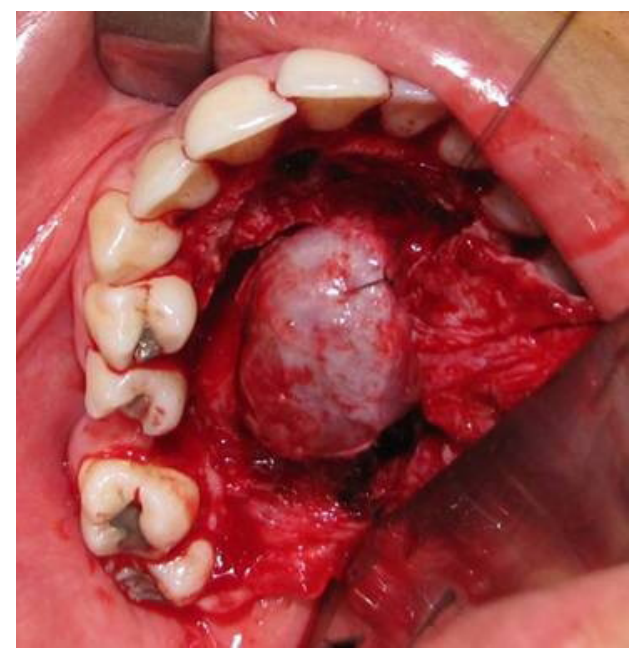

Figure 3. Clinical trans-operative appearance, demonstrating the complete removal of the lesion.
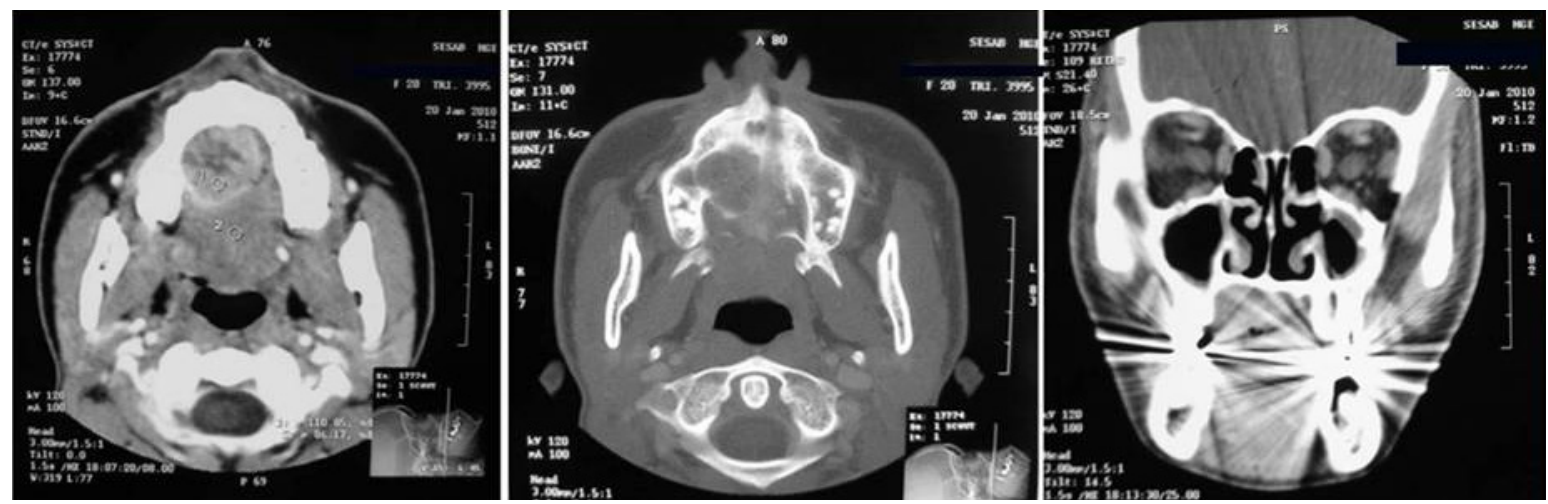

Figure 2. Computed tomography (axial and coronal sections) providing evidence of a well-defined, circumscribed lesion, with an area of superficial osteolysis on the hard palate, with no invasion of adjacent structures. 


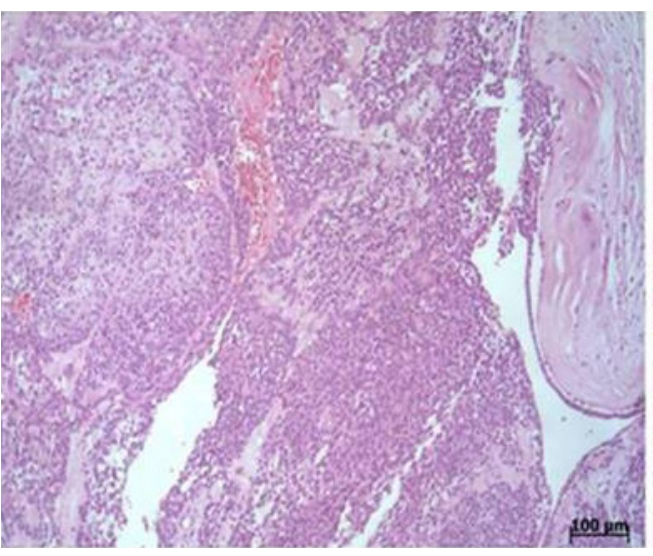

Figure 4. Microscopic view of the pleomorphic adenoma.

The histopathological examination of the surgical element found evidence of a well-defined, pseudo-encapsulated nodular lesion, characterized by a proliferation of epithelial and plasmocytoid myoepithelial cells and ductal elements with pairs of cells, squamous metaplasia and areas of cyst formation with a conclusive diagnosis of pleomorphic adenoma of the minor salivary glands (Figure 4).

The patient progressed satisfactorily in the postoperative period and after twenty days the region of the surgery can be said, clinically, to have completely healed. The patient has been clinically monitored for four months and no recurrence of the lesion has been observed (Figure 5).

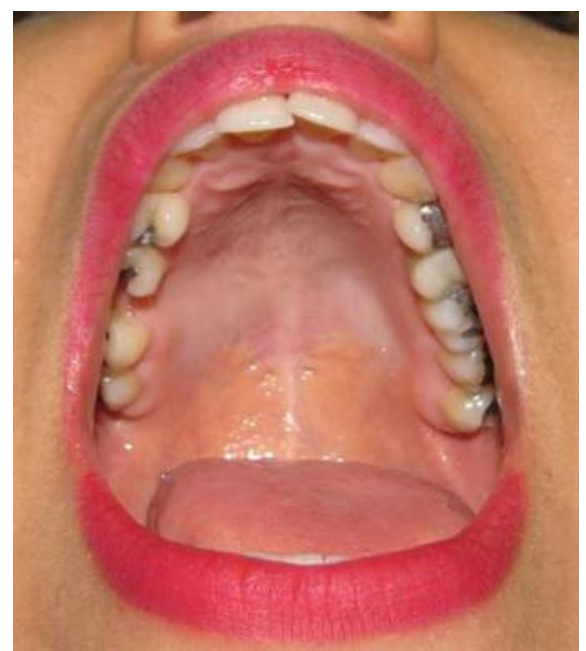

Figure 5. Final clinical appearance at 120 days post-op.

The patient was fully informed and made aware of the pre-op, trans-op and post-op details, authorized the execution of the treatment and the photographic documentation with the aim of publication and disclosure.

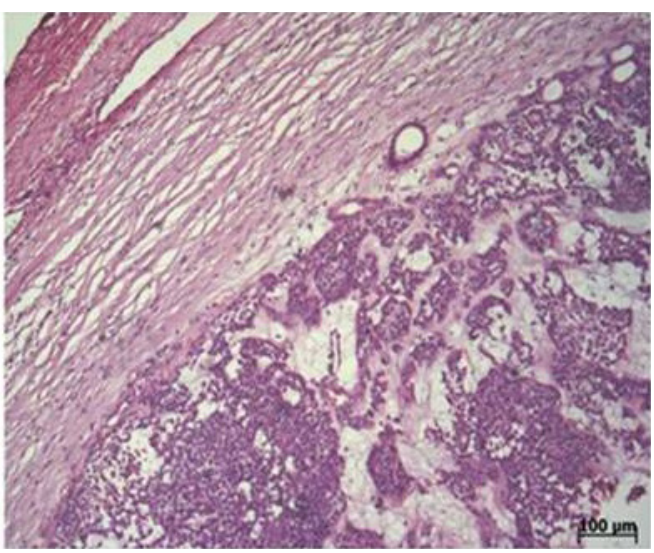

\section{DISCUSSION}

Neoplasms of the salivary glands are uncommon and represent around 3\% of all head and neck tumors ${ }^{12}$. The morphological diversity and variety of its biological behavior may determine difficulties with diagnosis and classification. The dental surgeon should be well aware of this and also the treatment since, in the majority of cases, early diagnosis results in more conservative treatment and a better prognosis for the patient ${ }^{16}$.

The pleomorphic adenoma is the most frequently found tumor amongst benign tumors of the salivary glands, afflicting both minor and major salivary glands, the parotid being the gland most affected $2-5,10-11$. It can appear at any age, though rarely in children $2,5,7,8,12$

Different retrospective, clinical-pathological studies in other parts of the world have shown that PA is the most common intraoral tumor of the salivary gland $\mathrm{d}^{9,18-19}$. It is also the most prevalent amongst tumors of the minor salivary glands, with the palate being the main location ${ }^{20-21}$, coinciding with the findings in the present study.

The knowledge that pleomorphic adenoma can also appear in unusual cervical-facial areas is important for the differential diagnosis of tumors in the head and neck region. There are reports of these tumors in the nasal septum, in the proximity of the temporomandibular joint, intraosseous spaces and in the lachrymal and breast glands $5,8,12,14,22$.

Though not mandatory, imaging examinations have been shown to be of great importance for differential diagnosis and treatment plan for pleomorphic adenomas of the salivary glands. Computed tomography shows itself to be superior in identifying the invasion of cortical bone and the presence of calcification and areas of necrosis inside 
the tumor mass, signals that represent, retrospectively, benignity and potential malignancy of the lesion ${ }^{11}$. RibeiroRotta et al. ${ }^{10}$ suggested that where magnetic resonance exams are available to the patient, it should be the first option for differential diagnosis and treatment planning.

Although the pleomorphic adenoma is a benign tumor of the salivary gland, the performance of a histopathological examination is extremely important since the clinical characteristics of this lesion may be similar to those present in malign tumors ${ }^{6,10}$.

The case reported in this study presented a wellcircumscribed, encapsulated, nodular lesion, with an extensive necrotic area in the center which made differential diagnosis difficult. Although areas of necrosis can certainly be associated with malignance, particularly with pleomorphic adenoma, such findings should not be analyzed in isolation as a sign of malignant transformation ${ }^{4,23}$.

Cases of necrosis can be divided into spontaneous and induced. However the etiology and pathogenesis of the necrosis remain unclear. Some authors have stated that necrosis of the pleomorphic adenoma can occur following aspiration puncture, where the possible etiological factor would be the interruption of microvascular supply, arising from vigorous aspiration of the tissue ${ }^{4}$. Other possibilities, with regard to a tumor located in the palate, could include the trauma factor, the systemic condition of the patient with a predisposition to ischemic necrosis of the tumor or even pressure on the major or minor palatine arteries, which would leave the lesion without blood supply and consequently lead to necrosis ${ }^{4,23}$.

According to Tanrikulu et al. ${ }^{3}$, with lesions of the palate, approximately $25 \%$ of mixed benign tumors suffer malignant transformation. Boros et al. ${ }^{12}$, however, stress that, although an assault on the minor salivary glands is less frequent than with the major glands, around $46 \%$ of neoplasms of the minor salivary glands are shown to be malignant, compared with no more than 15\% for the parotids. They also believe that it is not necessarily a malignant transformation of the pleomorphic adenoma but rather the preexistence of a malignant tumor together with the benign neoplasm.

\section{REFERENCES}

1. Lima SS, Soares AF, Amorim RFB, Freitas RA. Perfil epidemiológico das neoplasias de glândulas salivares: análise de 245 casos. Rev Bras Otorrinolaringol. 2005;71(3):335-40. doi: 10.1590/S003472992005000300012 .
According to Mcllveen et al. ${ }^{8}$ and Silva et al. ${ }^{15}$, the treatment of choice for pleomorphic adenomas in the posterior lateral region of the palate is the excision of the lesion together with the underlying periosteum, including the lining mucosa. Accordingly the possibility of a recurrence of the lesion through the rupture of the tumor capsule is reduced $1-3,6,10,15,24$. The treatment proposed for the clinical case presented in this study was the surgical removal of the lesion by means of an intrasulcular incision and mucoperiosteal detachment of the complete thickness, maintaining the lining mucosa; the tumor mass was welldefined with a satisfactory plane of cleavage.

Periodical post-operative monitoring should be performed so that the absence of signs of recurrence can be confirmed ${ }^{7}$. With the proper surgery, the prognosis is excellent, with a cure rate of over $95 \%$. Malignant degeneration is a potential complication, resulting in a carcinoma ex-pleomorphic adenoma, with reports varying between $5 \%$ and $23 \%$ of cases $^{2,5,6,20}$.

\section{CONCLUSION}

A knowledge of the morphological diversity and clinical-pathological variety of pleomorphic adenoma on the part of the dental surgeon is of great importance for carrying out early diagnosis and beginning suitable treatment.

Clinical pictures like the one presented here simulate malignant tumors and show the importance of the histopathological examination via the incisional biopsy on the recognition of this pathological condition.

\section{Collaborators}

RQ MOURA and CGC PONTES were responsible for the survey of the bibliography, case report and composition of the article. CS QUEIROZ and AI TRINDADE NETO were responsible for the execution of the clinical case, the preparation of images and the composition of the article. RA AZEVEDO provided guidance and took part in the final revision and composition of the article.

2. Neville BW, Damm DD, Allen CM, Bouquot JE. Tumores de glândulas salivares. In: Neville BW, Damm DD, Allen CM, Bouquot JE. Patologia oral e Maxilofacial. $3^{a}$ edição. Rio de Janeiro: Elsevier, 2009. p. 475-507.

3. Tanrikulu R, Yaman F, Atilgan S, Gunes N, Gorgun B. Interesting case: an unusual location for a large pleomorphic adenoma arising in the maxilla. J Int Dent Med Res. 2010;3(1):34-7. 
4. Chen YK, Lin CC, Lai $S$, Chen $C H$, Wang WC, Lin YR, et al. Pleomorphic adenoma with extensive necrosis: report of two cases. Oral Dis. 2004;10(1):54-9. doi: 10.1046/j.1354523X.2003.00966.x.

5. Forty MJ, Wake MJC. Pleomorphic salivary adenoma in an adolescent. Br Dent J. 2000;188():545-6. doi:10.1038/ sj.bdj.4800534.

6. Tiago RSL, Castro GA, Ricardo LAC, Bühler RB, Fava AS. Adenoma pleomórfico de parótida: aspectos clínicos, diagnósticos e terapêuticos. Rev Bras Otorrinolaringol. 2003;69(4):485-9. doi: 10.1590/S0034-72992003000400008.

7. Oliveira JGP, Barros RMG, Barros EG, Monteiro JCC, Martinez CR. Adenoma plemórfico em paciente infantil. Rev Cir Traumatol BucoMaxilofac. 2009;9(3):35-42.

8. Mcllveen LP, Sharp HK, Schuman, NJ. Pleomorphic adenoma of a minor salivary gland: report of a case. Quintessence Int. $1987 ; 18(3): 211-3$

9. Dhanuthai $K$, Boonadulyarat $M$, Jaengjongdee $T$, Jiruedee K. A clinico-pathologic study of 311 intra-oral salivary gland tumors in Thais. J Oral Pathol Med. 2009;38(6):495-500. doi: 10.1111/j.1600-0714.2009.00791.x.

10. Ribeiro-Rotta RF, Cruz ML, Paiva RR, Mendonça EF, Spini TH, Mendonça AR. O papel da ressonância magnética no diagnóstico do adenoma pleomórfico: revisão da literatura e relato de casos. Rev Bras Otorrinolaringol. 2003;69(5):699-707. doi: 10.1590/ S0034-72992003000500016.

11. Neves JC, Lima MCA, Sobra APV. Estudo clinicopatológico de 106 adenomas pleomórficos de glândula salivar maior. J Bras Patol Med Lab. 2007;43(5):347-54.

12. Boros LF, Bordini Júnior J, Boros LF, Boros LH, Silva PA. Adenoma pleomórfico de glândula salivar menor do palato. Odontologia Clin-Cienti. 2004;3(1):67-72.

13. Xu H, Shimizu Y, Niki T, Nagasaka H, Kawamura H, Ooya K. Pleomorphic adenoma of the submandibular salivary glands with marked ossification. J Oral Pathol Med. 2003;32(8):499501. doi: 10.1034/j.1600-0714.2003.00171.x.

14. Rocha MP, Campagnolo AM, Macedo VS, Scarton FB, Rocha HP, Kuhl G. Adenoma pleomórfico de septo nasal: relato de caso. Rev Bras Otorrinolaringol. 2004;70(3):416-8. doi: 10.1590/ S0034-72992004000300020.
15. Silva DN, Guimarães KB, Ferraro-Bezerra M, Heitz C. Enucleação de adenoma pleomórfico: considerações terapêuticas e relato de caso. Rev Cir Traumatol BucoMaxiloFac. 2007;7(4):25-30.

16. Lawall MA, Simonato LE, Ribeiro ACP, Crivelini MM, Moraes NP. Adenoma pleomórfico: relato de caso clínico. Rev Odontol Univ Cid de S Paulo. 2007; 9 (3):336-40

17. Lam KY, Ng IOL, Chan GSW. Palatal pleomorphic adenoma with florid squamous metaplasia: a potential diagnostic pitfall. J Oral Pathol Med. 1998;27(8):407-10.

18. Santos GC, Martins MR, Pellacani LB, Vieira ACT, Nascimento LA Abrahão M. Neoplasias de glândulas salivares: estudo de 119 casos. J Bras Patol Med Lab. 2003;39(4):371-5. doi: 10.1590/ S1676-24442003000400016.

19. Vargas PA, Gerhard R, Araújo Filho VJF, Castro IV. Salivary gland tumors in a Brazilian population: a retrospective study of 124 cases. Rev Hosp Clin. 2002;57(6):271-6. doi: 10.1590/S004187812002000600005 .

20. Rivera-Bastidas $\mathrm{H}$, Ocanto RA, Acevedo AM. Intraoral minor salivary gland tumors; a retrospective study of 62 cases in a Venezuelan population. J Oral Pathol Med. 1996;25(1):1-4.

21. Lopes MA, Kowalski LP, Santos GC, Almeida OP. A clinicopathologic study of 196 intraoral minor salivary gland tumours. J Oral Pathol Med. 1999;28(6):264-7.

22. Smolka W, Eggensperger N, Stauffer-Brauch EJ, Bredow F, lizuka T. Pleomorphic adenoma in an atypical location near the temporomandibular joint: a case report. 2007;38(5):417-21.

23. Allen CM, Damm D, Neville B, Rodu B, Page D, Weathers DR. Necrosis in benign salivary gland neoplasms. Not necessarily a sign of malignant transformation. Oral Surg Oral Med Oral Pathol. 1994;78(4):455-61.

24. Landini G. Nucleolar organizing regions (NORs) in pleomorphic adenomas of the salivary glands. J Oral Pathol Med. 1990;19(6):257-60 